\title{
Validation of Functioning Resistant Genes against Malaysian Biotype of Brown Planthopper in Rice Variety, Rathu Heenati
}

\author{
Mohamad Bahagia AB Ghaffar ${ }^{* \dagger}$, Ruziah Mohd Yusuf ${ }^{2 \dagger}$, Maisarah Mohamad Saad ${ }^{3}$, Muhammad Fairuz Mohd \\ Yusof $^{4}$, Shahril Ab Razak ${ }^{4}$, Habibuddin Hashim ${ }^{5 \dagger}$ and Noor Azmi Shaharuddin ${ }^{2 *}$ \\ ${ }^{1}$ Industrial Crop Research Centre, MARDI Seberang Perai, 13200 Kepala Batas, Pulau Pinang, Malaysia \\ ${ }^{2}$ Department of Biochemistry, Faculty of Biotechnology and Biomolecular Sciences \\ Universiti Putra Malaysia, 43400 UPM Serdang, Selangor, Malaysia \\ ${ }^{3}$ Paddy and Rice Research Centre, MARDI Seberang Perai, 13200 Kepala Batas, Pulau Pinang, Malaysia \\ ${ }^{4}$ Biotechnology \& Nanotechnology Research Centre, MARDI Headquarters, 43400, Serdang, Selangor \\ ${ }^{5}$ Agric Inov Resources. 08000 Sg Petani, Kedah, Malaysia \\ *For correspondence: bahagia@mardi.gov.my; noorazmi@upm.edu.my \\ Contributed equally to this work and are co-first authors \\ Received 30 June 2020; Accepted 29 November 2021; Published 30 January 2022
}

\begin{abstract}
Rathu Heenati is a donor parent commonly used in the development of resistant rice varieties against brown planthopper (BPH), Nilaparvata lugens, which is a devastating insect pest of rice. The variety is reported to have a broad-spectrum resistance against BPH, through the action of multiple genes and quantitative trait loci (QTL) including Bph3, Qbph3, Qbph4 and Qbph10. The present study was carried out to validate the effectiveness of those genes against Malaysian BPH population. The study was conducted using an $\mathrm{F}_{2}$ segregating population which was obtained from a cross between Rathu Heenati and a Malaysian commercial variety, MR219. Plant damage score was used to estimate the degree of plant tolerance, while the amount of honeydew excretion was used to measure the level of antibiosis. The gene presence in an individual plant was determined based on the segregation pattern of the flanking microsatellite markers of the respective reported genes. Results confirmed the role of Bph3 and the three other QTLs in conferring resistance against the Malaysian biotype of BPH. Marker assisted breeding can facilitate the monitoring of the introgressed genes in the plants of a breeding population. (C) 2022 Friends Science Publishers
\end{abstract}

Keywords: Oryza sativa L.; Brown plant hopper (BPH); Resistance gene; Quantitative trait locus; Microsatellite markers

\section{Introduction}

Rice (Oryza sativa L.) is one of the most important crops that feed more than three billion people in the world (Khush 2005; Yudo et al. 2018). It is estimated that the growing demand of the world population for rice consumption in 2030 would reach 873 million tons (Purevdorj and Kubo 2000; Yudo et al. 2018). This target however is being jeopardised by the loss of rice production in the field. Biotic factors contribute to a $52 \%$ reduction of global rice yield (Yarasi et al. 2008) where almost 21\% resulted from infestations by various species of insect pests. One of the major insects that cause a huge problem to rice is Brown Planthopper (BPH), Nilaparvata lugens (Stål). Many countries have reported that $\mathrm{BPH}$ greatly damaged the plant and significantly reduced the rice yield (Huang et al. 1997; Sogawa et al. 2003; Sun et al. 2005; Shabanimofrad et al. 2017). In Asia, the annual economic loss caused by $\mathrm{BPH}$ is estimated to be over $\$ 300$ million (Min et al. 2014; Yuexiong et al. 2019), with several devastating outbreaks previously reported in China, Vietnam, Philippines, Indonesia, Thailand, Japan, Korea, India, Bangladesh, and Malaysia (Heong 2009). BPH has long been identified as one of the most economically important insect pests of rice in Malaysia.

The utilization of resistant varieties is regarded as the most effective method in minimizing yield losses. Several $\mathrm{BPH}$ resistant varieties have been bred and released to farmers (Jairin et al. 2017). Currently, more than $30 \mathrm{BPH}$ resistant genes have been reportedly present in several rice varieties including in wild type species (Fujita et al. 2013; Sarao and Bentur 2016). To date, a Sri Lankan rice variety Rathu Heenati has shown high resistance and is resistant to all four $\mathrm{BPH}$ biotypes worldwide (Jairin et al. 2007a; Li et al. 2017), including the BPH population in Malaysia (Ito et al. 1994). The resistance of a variety to $\mathrm{BPH}$ is measured phenotypically through the mechanisms of antibiosis, plant tolerance, and antixenosis

To cite this paper: Ghaffar MBAB, RM Yusuf, MM Saad, MFM Yusof, SAB Razak, H Hashim, NA Shaharuddin (2022). Validation of functioning resistant genes against malaysian biotype of brown planthopper in rice variety, rathu heenati. Intl J Agric Biol 27:34-42 
(Bhanu et al. 2014; Hu et al. 2016). These mechanisms were used in the breeding and screening processes for the development of BPH resistant varieties.

Another breeding approach is currently available to breeders, i.e. the application of molecular markers in plant breeding, whereby selection is performed based on the presence or absence of genotypic markers instead of relying only on the observation of phenotypic expression. The selection of resistant plants using marker-assisted selection (MAS) is based on the linkage markers that are located nearby or on the resistant genes themselves. The introgression of desirable genes from one plant to another or from the parent plant to their progenies can be monitored through the presence of those markers (Mekonnen et al. 2017).

The Bph3 gene in Rathu Heenati was mapped on the short arm of chromosome 6 and is flanked by related markers, RM589 and RM588 (Jairin et al. 2007a). Previous studies have also shown that Rathu Heenati's resistance to $\mathrm{BPH}$ was also related to the presence of other genes such as the Bph17 and other minor quantitative trait loci, QTLs located on various chromosomes (Sun et al. 2005; Jairin et al. 2007a; Kumari et al. 2010; Hu et al. 2016). A QTL named Qbph3 is located on chromosome 3, positioned between markers RM313 and RM7. Whereas the second QTL, Qbph4 was found on the short arm of chromosome 4 between markers RM8213 and RM5953 with a map distance of $3.6 \mathrm{cM}$ and $3.2 \mathrm{cM}$. On the other hand, the Qbph10 was flanked by markers RM484 and RM496 on chromosome 10 (Sun et al. 2005).

This study aimed to validate the reported gene/QTLs that may have an association with the resistance of Rathu Heenati to the Malaysian biotype of BPH. While all the four genes/QTLs and their respective markers were known, the relative resistance expression of each of these resistant factors or multiple combinations of them is yet to be determined. Previous attempts using Rathu Heenati as donor parent failed to produce lines with resistance scores comparable to Rathu Heenati. It is then hypothesized that all the four resistant factors are responsible for the high resistance of Rathu Heenati. Assuring the presence of all the four genes in the breeding lines may ensure the development of highly resistant varieties. Marker-assisted selection could facilitate the monitoring and introgression of these gene/QTLs in the plants.

\section{Materials and Methods}

\section{Plant materials and insect population}

A total of $167 \mathrm{~F}_{2}$ progenies were derived from the cross of Rathu Heenati and MR219. Rathu Heenati (MRGB07637) is a traditional Sri Lankan rice variety and was used as the $\mathrm{BPH}$ resistant donor, whereas MR219 (MRGB11633) is a commercial high-yielding Malaysian variety that shows susceptibility to the current field population of BPH. Rice variety Taichung Native One (TN1) (MRGB01760) was used as the susceptible check variety. The BPH population used in the study was originally collected from rice fields surrounding the Malaysian Agricultural Research and Development Institute (MARDI) station in Seberang Perai, Malaysia. These insects were subsequently reared and maintained on seedlings of MR219 under greenhouse conditions. It was previously reported that MR219 harbored the Bphl gene (Habibuddin 2012) and hence, the insect population used in this study was expected to represent the Biotype-2 of BPH.

\section{Honeydew test}

Honeydew test is a test for the antibiosis mechanism of resistance. A piece of filter paper (Whatman No. 1) was dipped into a solution containing $0.02 \%$ of bromocresol green in ethanol (Pathak and Heinrichs 1982; Horgan et al. 2016). The experiment was conducted in a plant growth room at $22 \pm 3^{\circ} \mathrm{C}$ with $60 \pm 10 \%$ humidity and artificial photoperiodic lighting of 16h: $8 \mathrm{~h}$ (light: dark). The dried bromocresol green-treated filter paper was then placed at the base of individual 40-day-old plant samples inside a feeding chamber. The filter paper was placed $2 \mathrm{~cm}$ above the soil surface to protect the filter paper from excess humidity of the soil. Gravid brachypterous BPH females of similar age were starved for $2 \mathrm{~h} 30 \mathrm{~min}$ and 5 brachypterous $\mathrm{BPH}$ were subsequently released into the feeding chamber and left to feed on a single tiller for $24 \mathrm{~h}$. Honeydew droplets dropped onto the bromocresol green-treated filter paper. The area of each blue spot on the bromocresol green-treated filter papers was measured using a square $(\mathrm{mm})$ grid.

\section{Plant damage score test}

Plant damage score is a measure of plant damage tolerance upon infestation. The 5 brachypterous $\mathrm{BPH}$ and their nymphs were left to continue feeding on their respective test seedlings for 7-14 days or until yellowing or death of the MR219 test seedlings were first observed. Each test plant was scored individually according to the criteria established by the $5^{\text {th }}$ Standard Evaluation System (SES) (IRRI 2013) based on the damage (scale from 1 to 9) of individual plants as a result of the BPH feeding (Table 1).

\section{Extraction and quantification of DNA samples}

Genomic DNA was extracted from fresh, young leaves of Oryza sativa using the Taco ${ }^{\mathrm{TM}}$ Plant DNA Extraction Kit (GeneReach Biotechnology Corp, Taiwan) according to the manufacturer's protocol. The purified DNA was stored at $-20^{\circ} \mathrm{C}$. The concentration and quality of the extracted DNA were determined using NanoQuant ${ }^{\mathrm{TM}}$ spectrophotometer (TECAN Infinite 200 PRO, USA). 


\section{Evaluation of candidate markers}

Sets of flanking microsatellite markers linked to the respective $\mathrm{BPH}$ resistant genes were evaluated for their polymorphisms on the parental varieties. The selection of these markers was based on the previous study by Sun et al. (2005) who suggested the involvement of three different QTL regions in Rathu Heenati, namely Qbph3, Qbph4/Bph17 and Qbph10 and a major BPH resistant gene (Bph3). To enhance the density of markers used in this study, 56 microsatellite markers were further mined from the GRAMENE database (http://www.gramene.org/) based on their relative position surrounding the above mentioned gene and QTLs (Fig. 1). The best polymorphic, shortest distance to the respective targeted gene or QTLs were then selected for subsequent used in the study.

\section{Polymorphism of linked markers on $\mathrm{F}_{2}$ plants}

Only 8 polymorphic markers nearest to the target gene or QTLs were selected based on their preliminary polymorphism results. The selected polymorphic markers for the respective gene or QTLs were as follows: a) RM7 and RM1256 for Qbph3, b) RM8213 and RM5473 for Qbph4/Bph17, c) RM8072 and RM588 for Bph3, and d) RM5352 and RM5471 for Qbph10. Polymorphisms of the respective markers on individual $\mathrm{F}_{2}$ plants were assessed. The results of this test were subsequently merged with the corresponding data on plant resistance assessments.

\section{The expected presence of resistance loci on $\mathrm{F}_{2}$ plants}

The use of two flanking markers in the MAS breeding program could produce as high as 99 percent selection efficiency as compared to using a single marker (Kelly and Miklas 1998; Collard and MacKill 2008). The expected presence of a resistant gene locus in the individual $F_{2}$ plants was then based on the segregation pattern of their flanking markers, $\mathrm{A}$ and $\mathrm{B}$, on the left and right-hand sides of the gene, respectively. For example, 'AA' represented the homozygous genotype of marker $\mathrm{A}$, 'Aa' is heterozygous, and ' $a \mathrm{a}$ ' denotes the absence of marker $\mathrm{A}$ in a plant, and similarly with the marker B. Hence, the plants with their representative flanking markers genotypes as 'A_B_' are considered to have a gene for resistance at a $99 \%$ probability. Likewise, plants with either combination of 'A_bb' or ' $a a B$ ' genotypes may also indicate the presence of the resistant gene at $95 \%$ probability, depending on the proximity of the gene to the marker alleles A or B of Rathu Heenati. On the other hand, plants with the genotype of 'aabb' of MR219 were classified as individuals without the gene for resistance.

\section{Statistical analyses}

Data analysis was performed using Microsoft Excel. The
Pearson's Chi-square $\left(\chi^{2}\right)$ test was performed to evaluate the expected segregation ratio of the $F_{2}$ population in the Mendelian segregations. The $\chi^{2}$ value was estimated based on the procedure outlined by Panse and Sukhatme (2000) as shown below:

$$
\chi^{2}=\sum_{i=1}^{k} \frac{(0 i-E i)^{2}}{E i}
$$

With the degree of freedom $(\mathrm{df})=\mathrm{k}-1$, where $\mathrm{O}=$ Observed frequency of the class, $\mathrm{E}=$ Expected frequency of the respective class, $\sum=$ Summation of all classes. The nonsignificant $\chi^{2}$ values justified the agreement between the observed and expected ratio, therefore the null hypothesis is accepted as true.

The presence of a respective marker ' $\mathrm{A}$ ' in the individual $\mathrm{F}_{2}$ plants was genotyped as either 'AA', 'Aa' or homozygous 'aa'. The $\chi^{2}$ test was also used to test their expected 1:2:1 segregation ratio for a dominant factor. A co-segregation ratio of 9:7 was also tested for the cosegregation of the two-ends flanking markers A and B. The association between plants having respective resistant genes and their phenotypic resistance parameters was evaluated using association analysis (SAS version 9.3) where Cramer's V coefficient was used to measure the association strength. The relationship between genes and susceptible parameter was evaluated using correlation analysis (SAS version 9.1).

\section{Results}

\section{Honeydew test and plant damage scores of the parents}

The mean honeydew excretion (measured as area in $\mathrm{mm}^{2}$ ) obtained from the release of 5 gravids $\mathrm{BPH}$ on three rice varieties is presented in Table 2 . The honeydew excretions appeared as a blue-rimmed spot. As expected, the susceptible control variety (TN1) displayed the highest $\left(211.43 \pm 22.93 \mathrm{~mm}^{2}\right)$ mean score of honeydew spots. Likewise, the mean score of honeydew spots of MR219 was $185.71 \pm 16.74 \mathrm{~mm}^{2}$, which was slightly lower than that of TN1. In contrast, the honeydew droplet area of Rathu Heenati was only $45.71 \pm 6.17$. Additionally, a low coefficient of variation (CV) values was observed on TN1 (28.70\%) and MR219 (23.85\%), while Rathu Heenati showed a high CV value (40.93\%). A similar pattern was also shown for plant damage measurement. The mean score for susceptible varieties, TN1 and MR219, was 8.71 \pm 0.29 and $7.86 \pm 0.60$, respectively, while the lowest $(1.57 \pm 0.37)$ score was observed for the resistant donor parent, Rathu Heenati. The CV value was also recorded higher for Rathu Heenati as compared to MR219 and TN1. At the end of the study duration, almost all of the MR219 and TN1 plants were wilted and died due to heavy feedings by the BPH. These results confirmed the resistance of Rathu Heenati to BPH which was used as the donor parent and the susceptibility of MR219 as the recipient parent. 
Functioning Resistance Genes to BPH in Rathu Heenati / Intl J Agric Biol, Vol 27, No 1, 2022

Table 1: Modified damage rating score of the test plants following of a continuous BPH feeding (IRRI, 1998)

\begin{tabular}{lll}
\hline Scale & Description & Reaction \\
\hline 1 & No damage on the leaves & Highly resistant \\
3 & Very slight damage on the leaves & Resistant \\
5 & One to 2 leaves were yellowing & Moderately resistant \\
7 & More than half of the leaves shrank & Susceptible \\
9 & The plant died & Highly susceptible \\
\hline
\end{tabular}

Table 2: Overall mean scores ( \pm standard errors, SE) for BPH resistance and coefficient of variation $(\mathrm{CV})$ of parental and control rice varieties based on the honeydew and plant damage tests

\begin{tabular}{|c|c|c|c|c|c|c|}
\hline \multirow[t]{2}{*}{ Variety } & \multirow[t]{2}{*}{$\mathrm{N}$} & \multicolumn{4}{|c|}{ Resistance score (Mean \pm SE) } & \multirow{2}{*}{ Reaction } \\
\hline & & Honeydew $\left(\mathrm{mm}^{2}\right)$ & $\% \mathrm{CV}$ & Plant damage score & $\% \mathrm{CV}$ & \\
\hline Rathu Heenathi & 7 & $45.71 \pm 6.17$ & 40.93 & $1.57 \pm 0.37$ & 62.10 & $\mathrm{R}$ \\
\hline MR219 & 7 & $185.71 \pm 16.74$ & 23.85 & $7.86 \pm 0.60$ & 20.03 & $\mathrm{~S}$ \\
\hline TN1 (Control) & 7 & $211.43 \pm 22.93$ & 28.70 & $8.71 \pm .29$ & 8.67 & HS \\
\hline
\end{tabular}

$\mathrm{R}, \mathrm{S}$, and HS denote resistant, susceptible, and highly susceptible plants, respectively

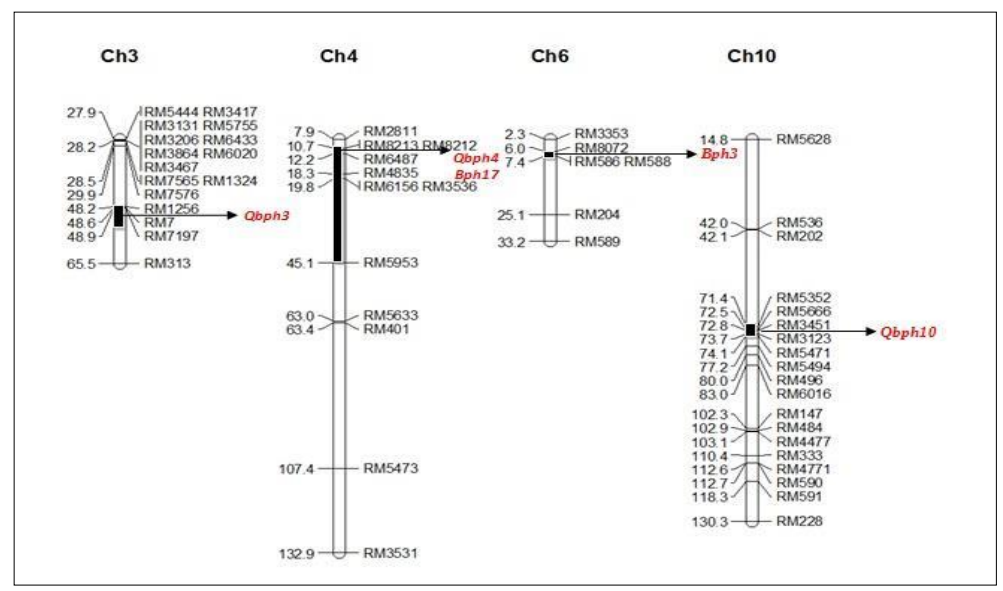

Fig. 1: Chromosomal location of BPH resistant genes and QTLs in the $F_{2}$ population. The marker names are listed on the right-hand side of the chromosome with the distance (in $\mathrm{cM}$ ) displayed on the left-hand side (Mapchart 2.30)

\section{Phenotypic segregation of $\mathrm{F}_{2}$ plants}

The frequency distribution of the $167 \mathrm{~F}_{2}$ plants against the amount of honeydew excretion displayed a continuous normal distribution, although it was slightly skewed towards the resistant parent with a mean score of $85.21 \mathrm{~mm}^{2}$ (Fig. 2), which may indicate that this antibiosis mode of resistance might be controlled by more than one gene. The majority of the progenies (119 plants) showed score values of $\leq 100 \mathrm{~mm}^{2}$, while Rathu Heenati and MR219 had score values of $42.0 \mathrm{~mm}^{2}$ and $181.0 \mathrm{~mm}^{2}$, respectively. However, the frequency distribution of $\mathrm{F}_{2}$ plants for plant damage scores is in bimodal distribution (Fig. 3). A total of 36 plants (including Rathu Heenati) displayed a score of 1 . These plants maintained their green-colored leaves even after 9 days of infestation. Additionally, $45 \mathrm{~F}_{2}$ plants had a score of 3 , and 23 plants were wilted and die and had a score of 9 (including MR219). Plants with scores of 1, 3, and 5 were pooled and classified as resistant, while plants with the scores of 7 and 9 were classified as susceptible. In total, 130 resistant plants and 37 susceptible plants were observed
(Table 3 ). The $\chi^{2}$ test showed that the phenotypic scoring of plant damage score was consistent with the expected Mendelian segregation ratio of 3:1, an indication of the role of a dominant gene effect. A similar result was also reported by $\mathrm{Hu}$ et al. (2018) who also conducted studies on Rathu Heenati. The results also showed that BPH faced difficulties to carry on with durable feeding or ingestion on the majority of the $F_{2}$ progenies, suggesting that these plants had been successfully introgressed with the resistant genes originated from Rathu Heenati.

\section{Segregation and Co-segregation of the flanking markers}

The segregation of individual markers in the $\mathrm{F}_{2}$ population was analyzed. Except for marker RM8072, results from the $\chi^{2}$ analysis show that the segregation of all other markers followed the 1:2:1 segregation ratio which suggested that each of these flanking markers was independently inherited as a dominant factor (Table 4). The calculated $\chi^{2}$ value for marker RM8072 was high (135.18), resulting in deviation from the expected ratio at $\mathrm{P}<0.001$, which could be due to 
Ghaffar et al. / Intl J Agric Biol, Vol 27, No 1, 2022

Table 3: Segregation of the $\mathrm{F}_{2}$ plants of Rathu Heenati $\mathrm{x}$ MR219 for resistance to BPH infestation based on their plant damage scores

\begin{tabular}{lll}
\hline Phenotypic expression of corresponding $\mathrm{F}_{2}$ plants & Expected $\mathrm{F}_{2}$ genotype & Observed number of $\mathrm{F}_{2}$ individuals \\
\hline $5 \leq$ Resistant & AA, Aa & 130 \\
Susceptible $\geq 7$ & aa & 37 \\
\hline$N=167$ & &
\end{tabular}

$\mathrm{N}=167$

Calculated $\chi^{2}$ value for $3: 1$ ratio is $0.720\left(\chi^{2} 0.05,1=3.841\right)$

The resistant plants are expected to possess homozygous AA or heterozygous Aa genomes inherited from Rathu Heenati, while the susceptible plants are carrying the 'aa' genome of MR219

Table 4: Segregation of marker alleles of eight microsatellite markers in the $F_{2}$ progenies derived from the cross of Rathu Heenati and MR219

\begin{tabular}{|c|c|c|c|c|c|c|}
\hline \multirow[t]{2}{*}{ Markers } & \multirow[t]{2}{*}{ Chr } & \multirow[t]{2}{*}{ Gene/QTL } & \multicolumn{3}{|c|}{ Ratio (1:2:1) } & \multirow[t]{2}{*}{$-\chi^{2}$} \\
\hline & & & $\overline{\mathrm{AA}}$ & $\mathrm{Aa}$ & aa & \\
\hline RM7 & 3 & Qbph3 & 44 & 69 & 45 & 2.54 \\
\hline RM1256 & & & 40 & 66 & 48 & 3.96 \\
\hline RM5473 & & & 33 & 76 & 49 & 3.44 \\
\hline RM8072 & 6 & Bph3 & 98 & 16 & 48 & 135.18 \\
\hline RM588 & & & 26 & 94 & 37 & 7.66 \\
\hline RM5471 & & & 33 & 72 & 44 & 1.78 \\
\hline
\end{tabular}

'AA' and 'aa' represent the genotypes of Rathu Heenati and MR219, respectively. 'Aa' is the heterozygous genotype.

Tabulated $\chi^{2} 0.05,0.01,0.001, \mathrm{df}_{2}=5.991,9.210$ and 13.82 , respectively

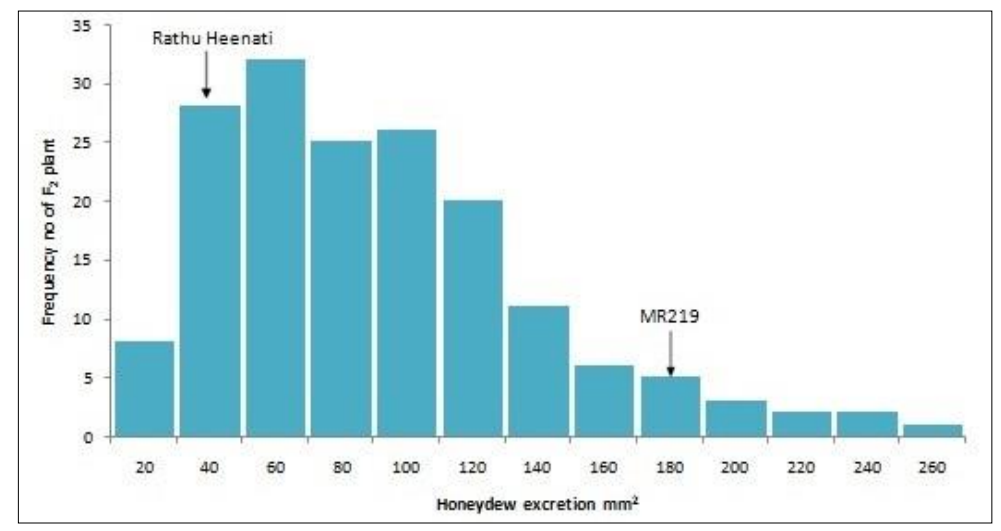

Fig. 2: Frequency distribution of the amount of honeydew excreted by BPH feeding on the $\mathrm{F}_{2}$ population of Rathu Heenati/MR219, N=169

segregation distortion. This distortion was due to the high frequency number of AA (98) and the lesser number of the heterozygous Aa (16) genotypes. The cause of this segregation distortion could be genetic and environmental factors. This segregation distortion phenomenon was commonly found during population mapping due to biological selection or sampling, and this phenomenon usually interferes with the creation of genetic maps (Xu et al. 1997; Soundararajan et al. 2004).

In this study, two flanking markers were assumed to be closely linked if they were inherited in an allelic or cosegregated manner, of which the flanked gene is positioned between them. The plants with genotypes 'A_B_' are highly predicted to harbor resistant genes originated from Rathu Henati, while the plants which co-segregated with the genotype 'aabb' may indicate the absence of the resistant gene as the alleles were inherited from MR219. Our results showed that the calculated $\chi^{2}$ value for the co-segregation of markers RM8213 and RM5473 is 0.31 (Table 5), a value lower than that of the tabulated value at $\mathrm{P}>0.05$, thus suggesting that the two flanking markers are closely linked, co-segregated and hence the possibility for the presence of the gene $Q b p h 4$ between them is very high. The calculated $\chi^{2}$ values for the co-segregation of $Q b p h 3$ and $Q b p h 10$ markers, respectively were also low, albeit at a lower confidence level of $\mathrm{P}>0.01$, and may still support the acceptance of the 9:7 ratio. On the other hand, the $\chi^{2}$ value for the marker set RM588/RM8072 of Bph3 was relatively high $(\mathrm{P}>001)$, due to distortion resulting from a higher number of 'A_B_' relative to other genotypes. The coexisting of both the flanking markers in a plant indicated that they inherited resistant genes from Rathu Heenati at the particular loci.

\section{Association between the gene presence and phenotypic expression of the plants}

An association analysis was conducted to estimate the 
Functioning Resistance Genes to BPH in Rathu Heenati / Intl J Agric Biol, Vol 27, No 1, 2022

Table 5: Co-segregation of the flanking markers of the four putative BPH resistant genes in the $\mathrm{F}_{2}$ progenies of Rathu Heenati and MR219 cross

\begin{tabular}{|c|c|c|c|c|}
\hline $\begin{array}{l}\text { Flanking Markers } \\
\text { (Gene) }\end{array}$ & $\begin{array}{l}\text { RM7/ } \\
\text { RM1256 } \\
\text { (Qbph3) }\end{array}$ & $\begin{array}{l}\text { RM8213/ } \\
\text { RM5473 } \\
\text { (Qbph4) }\end{array}$ & $\begin{array}{l}\text { RM588/ } \\
\text { RM8072 } \\
(\text { Bph3) } \\
\end{array}$ & $\begin{array}{l}\text { RM5471/ } \\
\text { RM5352 } \\
\text { (Qbph10) }\end{array}$ \\
\hline Segregation ratio & $9: 7$ & $9: 7$ & $9: 7$ & $9: 7$ \\
\hline Observed & 101: 53 & 81: 69 & 108: 49 & 64: 71 \\
\hline$\chi^{2}$ & 5.45 & 0.31 & 10.03 & 4.28 \\
\hline
\end{tabular}

Tabulated $\chi^{2} 0.05,0.01,0.001, \mathrm{df1}=3.841,6.635$ and 10.828 , respectively

$\mathrm{H}_{0}=$ The segregation ratio of the flanking markers is in the ratio of 9:7 for the A_B_: other allele combinations, respectively

Table 6: The association of putative gene or QTLs and the phenotypic expression of the F2 plants

\begin{tabular}{lllll}
\hline & & Plant damage score (Tolerance) & \multicolumn{2}{l}{ Honeydew excretion (Antibiosis) } \\
\cline { 2 - 5 } Gene combination & $\chi^{2}$ & Cramer's V coefficient & $\chi^{2}$ & Cramer's V coefficient \\
\hline Bph3 & $16.1910^{*}$ & 0.4172 & $29.6626^{*}$ & 0.5588 \\
Qbph3 & $12.260^{*}$ & 0.3442 & $19.7283^{*}$ & 0.4420 \\
Qbph4 & $13.2328^{*}$ & 0.3946 & $32.6712^{*}$ & 0.5632 \\
Qbph10 & $12.9218^{*}$ & 0.3994 & $20.7747^{*}$ & 0.5064 \\
\hline *
\end{tabular}

*Significant at $\mathrm{P}=0.05$

Cramer's V coefficient: V=0.25-0.75 (moderately strong)

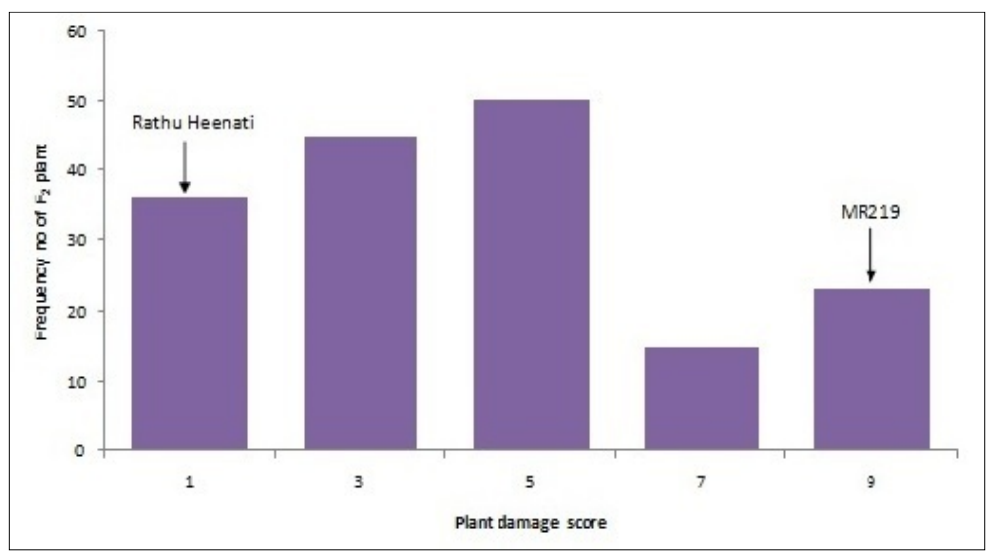

Fig. 3: Frequency distribution of $F_{2}$ plants of a cross between Rathu Heenati and MR219 when based on the plant damage scores following the infestation by $\mathrm{BPH}$

The scores of Rathu Heenati and MR219 as control varieties were 1 and 9, respectively, $\mathrm{N}=169$

association between the presence of $B p h 3$ gene or the other three respective QTLs in a plant and their phenotypic expression. All the $\chi^{2}$ values are significant at $\mathrm{P}<0.05$ (Table 6 ). These results indicated that the resistance expression of a plant is associated with the respective gene or QTL harbored by them. Plants harboring any of those resistant genes showed degrees of resistance expressed in the form of plant damage score and levels of antibiosis, as compared to those plants without any of the resistant gene or QTL. The strength of association between genes presence and the expression of the phenotypes is measured by Cramer's V coefficient, which is moderate.

Rathu Heenati as the donor parent is harboring Bph3 gene and three other QTLs. The variety showed the lowest plant damage score of 1.80 as compared to the susceptible (without any gene) MR219 with the score of 8.00, indicating the high level of BPH resistance in Rathu Heenati (Table 7). A similar pattern of resistance expression is also demonstrated in the form of honeydew excretion, where the area of honeydew droplets in Rathu Heenati is $42 \mathrm{~mm}$, significantly lower than that of MR219 (181.0 mm). The $F_{2}$ plants in groups with different gene combinations showed variable degrees of resistance, mostly moderate. The $F_{2}$ plants in the group ABCD which are having all the four genes showed a low plant damage score (2.27) and a small honeydew droplet area $(46.36 \mathrm{~mm})$, which are not significantly different from that of Rathu Heenati, demonstrated an equivalent level of resistance to that of Rathu Heenati. A correlation analysis was also conducted to estimate the relationship between plant damage score resulted from the $\mathrm{BPH}$ feeding and the amount of honeydew excreted by those feeding BPH. A high correlation coefficient value was observed between the two parameters $(\mathrm{r}=0.83009 * * *)$, which was as expected, which supported the assumption that excessive feeding, draining of the water, and nutrients from the plants in the form of honeydew, lead to their wilting and death of the plants. 
Ghaffar et al. / Intl J Agric Biol, Vol 27, No 1, 2022

Table 7: Plant damage score and honeydew excretion on plants with different number of BPH resistant gene and QTLs

\begin{tabular}{|c|c|c|c|c|c|}
\hline Gene/QTL combination & No. of gene & & mage score & & etion $\left(\mathrm{mm}^{2}\right)$ \\
\hline MR219 (Susceptible parent) & 0 & 8.0 & $\mathrm{ab}$ & 181.0 & $\mathrm{a}$ \\
\hline No gene $(\mathrm{H})$ & 0 & 7.7 & a & 143.3 & $\mathrm{ab}$ \\
\hline$B p h 3(\mathrm{~A})$ & 1 & 4.4 & cdef & 77.9 & bcdef \\
\hline Qbph3 (B) & 1 & 4.6 & bcde & 88.2 & bcde \\
\hline Qbph4 (C) & 1 & 1.0 & $\mathrm{f}$ & 30.0 & ef \\
\hline Qbph10 (D) & 1 & 3.7 & cdef & 66.7 & cdef \\
\hline Bph3/Qbph3 (AB) & 2 & 4.3 & cdef & 76.5 & bcdef \\
\hline Bph3/Qbph4 (AC) & 2 & 7.0 & $a b c$ & 110 & bed \\
\hline Bph3/Qbph10 (AD) & 2 & 4.3 & cdef & 76.7 & bcdef \\
\hline Qbph3/Qbph4 (BC) & 2 & 5.3 & abcde & 113.3 & $\mathrm{bc}$ \\
\hline Qbph3/Qbph10 (BD) & 2 & 1.0 & $\mathrm{f}$ & 10.0 & $\mathrm{f}$ \\
\hline Qbph4/Qbph10 (CD) & 2 & 3.8 & cdef & 69.0 & cdef \\
\hline Bph3/Qbph3/Qbph4 (ABC) & 3 & 5.4 & abcde & 94.5 & bcde \\
\hline Bph3/Qbph3/Qbph10 (ABD) & 3 & 5.8 & abcd & 107.5 & bcd \\
\hline Bph3/Qbph4/Qbph10 (ACD) & 3 & 2.8 & def & 51.1 & cdef \\
\hline Qbph3/Qbph4/Qbph10 (BCD) & 3 & 5.0 & abcde & 107.1 & bed \\
\hline Bph3/Qbph3/Qbph4/Qbph10 (ABCD) & 4 & 2.3 & def & 46.4 & cdef \\
\hline Rathu Heenati (Resistant parent) & 4 & 1.8 & ef & 42.0 & def \\
\hline
\end{tabular}

Means within a column with a similar letter are not significantly different by DMRT

\section{Discussion}

Identification of suitable resistant candidate genes is one of the most important steps in an effective resistant breeding program. Therefore, there is a need to validate all reported genes of interest towards the local BPH population to make sure their effective function, and that the breeding activity could be carried out effectively at a reasonable cost. In this study, a Sri Langkan rice variety, Rathu Heenati, has been selected to be used as the donor of resistant genes and QTLs for the development of local rice varieties resistant against $\mathrm{BPH}$, Nilaparvata lugens. The level of BPH resistance in Rathu Heenati was measured and compared to the susceptible check variety TN1 and the recurrent parent MR219. The measurement was based on the assessment of the quantity of honeydew excreted area by BPH sucking on the plant (as an antibiosis assessment) and the plant damage score following BPH infestation (an assessment for plant tolerance). From the antibiosis perspective, the BPH feeding on Rathu Heenati excreted the lowest amount of honeydew excretion as compared to those feeding on MR219 or TN1. The low amount of honeydew excretion on Rathu Heenati could be due to the difficulties in phloem ingestion by the $\mathrm{BPH}$, thus contributing to the variety's resistance. The higher coefficient of variation $(\mathrm{CV})$ value recorded in Rathu Heenati as compared to those on MR219 and TN1 showed clear evidence of the inconsistency of BPH feeding ability on Rathu Heenati as the proportion of honeydew droplets of BPH is hugely influenced by its host varieties (Ghaffar et al. 2011).

Because of the inability of BPH to consistently feed on the resistant rice plant, the feeding data as measured by the level of antibiosis has also contributed to plant tolerance measurement data where Rathu Heenati also showed the lowest plant damage score. This result was in line with the observation of Akanksha et al. (2019) who showed that the amount of honeydew excretion and plant damage was highly correlated and significantly affected by host varieties.
It was previously demonstrated that BPH primarily fed on the phloem of the susceptible varieties, ingesting high-value nutrients such as amino acids to support its growth and reproduction. During the early phase of stylet penetration in Rathu Heenati, undesirable constituent elements in the variety may disturb the BPH and prevent effective phloem ingestion (Ghaffar et al. 2011). This mechanism thus enables resistant plants to survive BPH attacks. The inability to consistently feeding on the host plant has caused less injury to the plant's tissues and hence the potential plant dehydration and loss of nutrients was prevented. This describes the reason behind the lower plant damage scores recorded in Rathu Heenati as compared to the scores on the susceptible control variety TN1 and MR219. This result confirmed the earlier reports by Habibuddin (1989) and Jairin et al. (2007) claiming that Rathu Heenati showed high and broad-spectrum resistance characteristics to $\mathrm{BPH}$ populations in Thailand and Malaysia, respectively. The variety is thus a very good candidate donor parent for used in the local BPH resistant breeding program.

However, the strong resistance of Rathu Heenati to $\mathrm{BPH}$ of variable biotypes, in multiple localities and countries is attributed to its harboring of at least the $B p h 3$ gene and the three mentioned QTLs, the Qbph3, Qbph4 and Qbph10. Many attempts in the previous BPH resistance breeding program which utilized Rathu Heenati as the donor parent produced progenies or new varieties with moderate levels of resistance. Breeders have difficulty in developing new cultivars having the equivalent levels of BPH resistance to that of Rathu Heenati. This could be due to the failure to transfer or ensuring the maintenance of all the relevant genes or QTLs in the newly developed varieties. Our results in Table 7 showed that different $F_{2}$ plants may harbor different combinations of BPH resistant genes or QTLs in the plants, resulting in the variable degree of resistance to BPH. To ensure the subsequent progenies or generations of the crosses involving Rathu Heenati to continuously harbor the 
desired gene or QTL is a difficult task when resistance assessment is solely based on phenotypic expression.

Application of marker assisted selection (MAS) in resistant breeding programs may offer an opportunity to overcome this limitation. Linked or functional markers could be used to determine the presence or absence of the genes in the plants. Through MAS, the introgression of genes would be monitored among breeding lines from generation to generation until the new varieties are ready to be selected for released and commercialized. This study showed that the introgression of the four genes and QTLs could be ascertained, and newly improved, resistant Malaysian major varieties could be developed, having a resistance level to BPH which is equivalent to that of Rathu Heenathi.

\section{Conclusion}

This study confirmed that the resistance of Rathu Heenati to BPH is controlled by Bph3 gene and three other QTLs, namely the $Q b p h 3, Q b p h 4$ and $Q b p h 10$. The introgression of these four resistant factors in the plants and breeding lines could be monitored through the detection of their flanking microsatellite markers. Application of marker-assisted selection (MAS) could thus enhance resistant breeding programs and the development of resistant or improved popular major cultivars is much easier to achieve.

\section{Acknowledgements}

This research was supported by The Ministry of Energy, Science, Technology, Environment and Climate Change (MESTECC) through the project grant FLAGSHIP No: TF FP0214B055 (DSTIN) and Malaysia Agriculture Research and Development Institute (MARDI).

\section{Author Contributions}

MBAG, RMY and NAS planned the experiments, MBAG, MMS and SAR interpreted the results, MBAG, HH and RMY made the write up and MF statistically analyzed the data and made illustrations.

\section{Conflicts of Interest}

The authors declare no conflicts of interest

\section{Data Availability}

All data were presented in this paper and additional information can be obtain from corresponding author

\section{Ethics Approval}

Not applicable in this paper

\section{References}

Akanksha S, VJ Lakshmi, AK Singh, Y Deepthi, PM Chirutkar, Ramdeen, D Balakrishnan, N Sarla, SK Mangrauthia, T Ram (2019). Genetics of novel brown planthopper Nilaparvata lugens $\left(\mathrm{Sta}^{\circ} \mathrm{l}\right)$ resistance genes in derived introgression lines from the interspecific cross $O$. sativa var. Swarna 3 O. nivara. J Gen 98:113

Bhanu KV, VJ Lakshmi, G Katti, AV Reddy (2014). Antibiosis and tolerance mechanisms of resistance in rice varieties carrying brown planthopper resistance genes. Asian J Biol Life Sci 3:108-113

Collard BC, DJ Mackill (2008). Marker-assisted selection: An approach for precision plant breeding in the twenty-first century. Phil Transactions Royal Soc London B: Biol Sci 363:557-572

Fujita D, A Kohli, FG Horgan (2013). Rice resistance to planthoppers and leafhoppers. Crit Rev Plant Sci 32:162-191

Ghaffar MBAB, J Pritchard, B Ford-Lloyd (2011). Brown Planthopper (Nilaparvata lugens Stal) Feeding Behaviour on Rice Germplasm as an Indicator of Resistance. PLoS One 6:e22137

Habibuddin H (1989). Variation of brown planthopper population from major rice regions of Peninsular Malaysia. MARDI Res J 17:218224

Habibuddin H (2012). Managing pests and diseases of rice using resistant varieties. Res Inaugural Lecture. MARDI, Serdang, Malaysia

Heong KL (2009). Planthoppers - New Threats to the Sustainability of Intensive Rice Production Systems in Asia. In: Are Planthopper Problems Due to Breakdown In Ecosystem Services, pp:231-232. Heong KL, B Hardy (Eds). International Rice Research Institute, Los Banos, Philippines

Horgan FG, TS Srinivasan, BS Naik, AF Ramal, CC Bernal, MLP Almazan (2016). Effects of nitrogen on egg-laying inhibition and ovicidal response in planthopper-resistant rice varieties. Crop Protec 89:223230

Huang N, A Parco, T Mew, G Magpantay, S McCouch, E Guiderdoni, GS Khush (1997). RFLP mapping of isozymes, RAPD and QTLs for grain shape, brown planthopper resistance in a doubled haploid rice population. Mol Breed 3:105-113

$\mathrm{Hu}$ J, C Xiao, C He (2016). Recent progress on the genetics and molecular breeding of brown planthopper resistance in rice. Rice 9:30

Hu J, XY Chang, L Zou, WQ Tang, WR Wu (2018). Identification and fine mapping of Bph33, a new brown planthopper resistance gene in rice (Oryza sativa L.). Rice 1:55

IRRI (2013). Standard Evaluation System for Rice (SES), p:55. $5^{\text {th }}$ edn. Los Banos. Philippines

Ito K, T Wada, A Takahashi, NS Nik, M Noor, H Habibuddin (1994). Brown planthopper, Nilaparvata lugens Stål (Homoptera: Delphacidae) biotypes capable of attacking resistant rice varieties in Malaysia. Appl Entomol Zool 29:525-534

Jairin J, K Phengrat, S Teangdeerith, A Vanavichit, T Toojinda (2007a). Mapping of a broad-spectrum brown planthopper resistance gene, Bph3, on rice chromosome 6. Mol Breed 19:35-44

Jairin J, P Leelagud, T Saejueng, V Chamarerk (2017). Loss of resistance to Nilaparvata lugens may be due to the low-level expression of BPH32 in rice panicles at the heading stage. Amer J Plant Sci 8:2825-2836

Kelly JD, P Miklas (1998). The role of RAPD markers in breeding for disease resistance in common bean. Mol Breed 4:1-11

Khush GS (2005). What it will take to feed 5 billion rice consumers in 2030. Intl J Mol Biol Vol. 59:1-6

Kumari S, JM Sheba, M Marappan, S Ponnuswamy, S Seetharaman, SN Pothi (2010). Screening of IR50× Rathu Heenati F7 RILs and identification of SSR markers linked to brown planthopper (Nilaparvata lugens Stål) resistance in rice (Oryza sativa L.). Mol Biotechnol 46:63-71

Li C, C Luo, Z Zhou, R Wang, F Ling, L Xiao, Y Lin, H Chen (2017). Gene expression and plant hormone levels in two contrasting rice genotypes responding to brown planthopper infestation. BMC Plant Biol 17:57 
Mekonnen T, T Haileselassie, K Tesfaye (2017). Identification, mapping and pyramiding of genes/quantitative trait loci (QTLs) for durable resistance of crops to biotic stress. J Plant Pathol Microbiol 8:412

Min S, SW Lee, BR Choi, SH Lee, DH Kwon (2014). Insecticide resistance monitoring and correlation analysis to select appropriate insecticides against Nilaparvata lugens (Stål), amigratory pest in Korea. J Asia Pac Entomol 17:711-716

Pathak PK, EA Heinrichs (1982). Bromocresol green indicator for measuring feeding activity of Nilaparvata lugens on rice varieties. Phil Entomol 5:e198

Panse VG, PV Sukhatme (2000). Statistical Methods for Agricultural Workers. Ind Council Agric Res pp:68-87, India

Purevdorj M, M Kubo (2000). The future of rice production, consumption and seaborne trade: Synthetic prediction method. J Food Distribution Res 36:250-259

Sarao PS, JS Bentur (2016). Antixenosis and tolerance of rice genotypes against brown planthopper. Rice Sci 23:96-103

Sogawa K, GJ Liu, JH Shen (2003). A review on the hyper-susceptibility of Chinese hybrid rice to insect pests. Chin J Rice Sci 17:23-30

Shabanimofrad M, MY Rafii, S Ashkani, MM Hanafi, NA Adam, AR Harun, MA Latif, G Miah, M Sahebi, P Azizi (2017). Mapping of QTLs conferring resistance in rice to brown planthopper, Nilaparvata lugens. Entomologia Experimentalis et Applicata 162:60-68
Soundararajan RP, P Kadirvel, K Gunathilagaraj, M Maheswaran (2004). Mapping of quantitative trait loci associated with resistance to brown planthopper in rice by means of a doubled haploid population. Crop Sci 44:2214-2220

Sun LH, C Su, C Wang, H Zai, J Wan (2005). Mapping of a major resistance gene to brown planthopper in the rice cultivar Rathu Heenati. Breed Sci 55:391-396

Xu Y, L Zhu, J Xiao, N Huang, SR McCouch (1997). Chromosomal regions associated with segregation distortion of molecular markers in F2, backcross. Double haploid and recombinant inbred populations in rice (Oryza sativa L.). Theoretical Appl Genet 253:535-545

Yarasi B, V Sadumpati, CP Immanni, DR Vudem, VR Khareedu (2008). Transgenic rice expressing Allium sativum leaf agglutinin (ASAL) exhibits high-level resistance against major sap-sucking pests. $B M C$ Plant Biol 8:102

Yudo P, S Abdi, WA Kurnia, JPSA Bernardinus (2018). Rice productivity prediction model design based on linear regression of spectral value using NDVI and LSWI combination on landsat-8 imagery, IOP Conference Series: Earth Environ Sci 165:12002

Yuexiong Z, QIN Gang, MA Qianqian, WEI Minyi, YG Xinghai, MA Zengfeng (2019). Identification of a major resistance locus Bhp35 to brown planthopper in rice (Oryza sativa L.). Rice Sci 27:237-245 